\title{
In-vivo T2 mapping of atherosclerotic plaques in carotid arteries
}

\author{
Luca Biasiolli ${ }^{1 *}$, Alistair C Lindsay ${ }^{1,2}$, Robin P Choudhury ${ }^{1}$, Matthew D Robson ${ }^{1}$ \\ From 15th Annual SCMR Scientific Sessions \\ Orlando, FL, USA. 2-5 February 2012
}

\section{Summary}

The purpose of this study was to measure the T2 relaxation times of carotid atherosclerotic plaque components in-vivo at $3 \mathrm{~T}$ and show the potential application of $\mathrm{T} 2$ mapping for plaque segmentation.

\section{Background}

Clinical studies that have measured plaque T2 times were mostly performed ex-vivo using a small number of plaques excised from different arterial locations and imaged at different field strength using a limited number of TEs. The Table shows that T2 measured in the lipidrich necrotic core (LRNC) was consistently shorter than $\mathrm{T} 2$ in fibrous tissue or in normal media, which showed similar values. The only two studies of carotid plaques showed a comparable T2 range for LRNC and fibrous tissue regardless of field strength difference.

\section{Methods}

12 patients with stable atherosclerosis ( 9 males, $72 \pm 11$ years) were imaged on a $3 \mathrm{~T}$ scanner (Siemens TIM Trio). Ethics approval from local board was obtained and subjects gave informed consent. A multiple-SpinEcho (multi-SE) sequence (Spin-Echo_Multi-Contrast or SE_MC) with low SAR pulses acquired black-blood cross-sectional images of carotid arteries using a 4-channel surface coil and cardiac gating $(\mathrm{TE}=25.8-38.7-51.6$ 64.5-77.4-90.3-103.2ms, TR=2R-R, FOV $=160 \times 128 \mathrm{~mm} 2$, matrix - size $=320 \times 256$, slice-thickness $=2 \mathrm{~mm}$, partial Fourier $=5 / 8$ ). T2 was estimated for every voxel of the carotid wall by fitting a mono-exponential decay curve to the signal intensities at 7 TEs using non-linear leastsquares regression. Using a semi-automated method based on Bayes classifiers, T2 maps of carotid arteries were segmented in 4 tissue types: calcification; LRNC; fibrous tissue and normal media; intra-plaque haemorrhage. Histological validation was not available. AHA plaque classification was performed by two blinded reviewers on multi-contrast images acquired separately.

\section{Results}

23 carotid arteries presented visible lesions graded using the MRI-modified AHA scheme: 10 type III, 7 type IVV, 2 type VI, 2 type VII and 2 type VIII plaques. From the T2 map segmentation of these arteries (Figure 1), 3438 voxels were classified as LRNC with T $2=36 \pm 5 \mathrm{~ms}$ and 10291 voxels as fibrous tissue or normal media with $\mathrm{T} 2=55 \pm 9 \mathrm{~ms}$ (Table 1 ). Due to low proton density, calcification produced insufficient SNR and T2 could not be measured. 1212 voxels were classified as haemorrhage with T2 $=89 \pm 20 \mathrm{~ms}$ (some were incorrectly included due to $\mathrm{T} 2$ overestimation).

\section{Conclusions}

This study showed the potential of in-vivo T2 mapping for atherosclerotic plaque characterization using Multi$\mathrm{SE}$ in carotid imaging. T2 relaxation times measured invivo for LRNC and fibrous tissue or media at $3 \mathrm{~T}$ were consistent with the range of values reported in literature for carotid plaques.

\section{Funding}

This study was funded by EPSRC.

\section{Author details \\ ${ }^{1}$ Cardiovascular Medicine, University of Oxford, Oxford, UK. ${ }^{2}$ Royal Brompton Hospital, London, UK.}

Published: 1 February 2012 

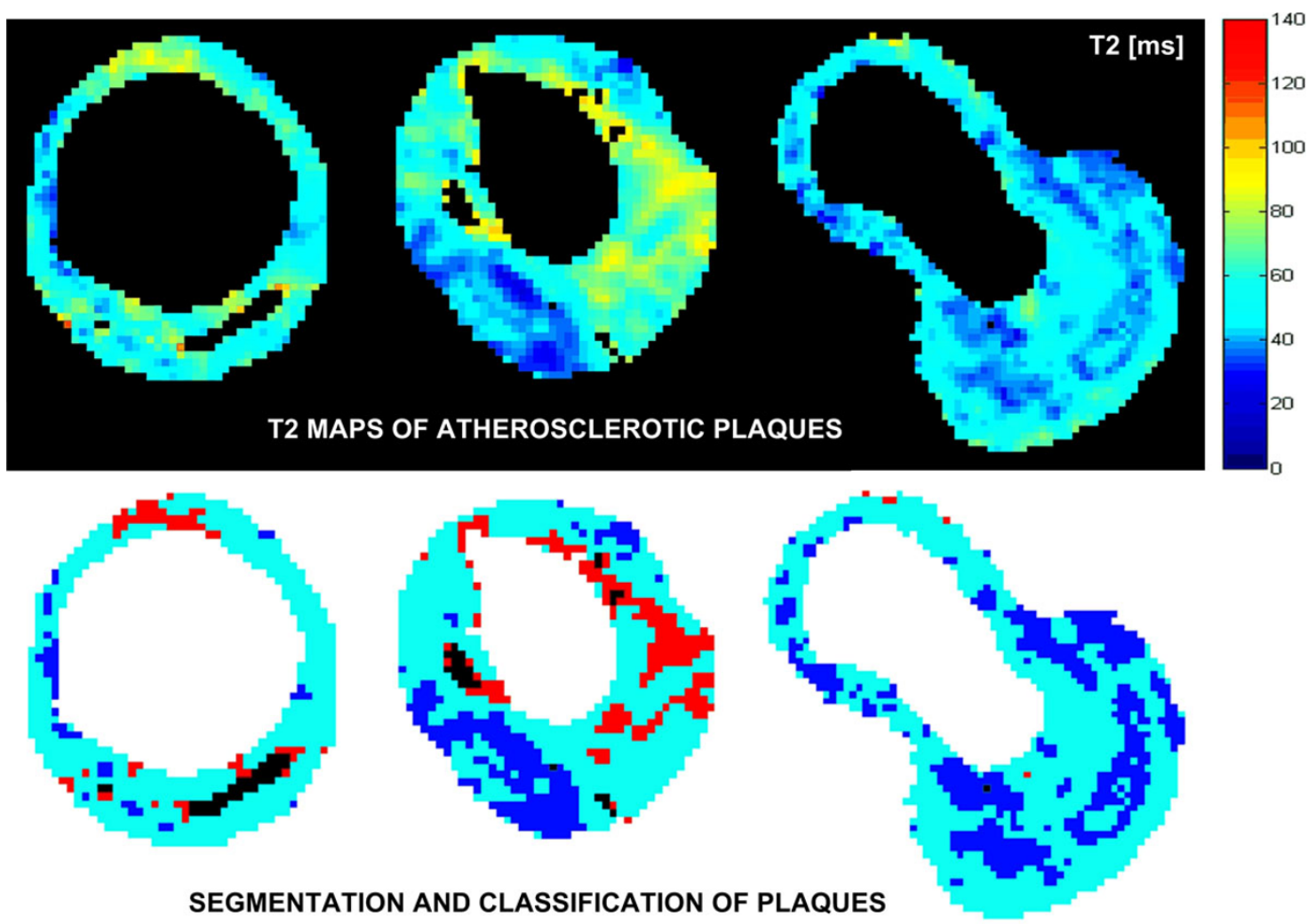

\section{SEGMENTATION AND CLASSIFICATION OF PLAQUES}

\section{\begin{tabular}{l|l|l|l} 
Calcification & LRNC & Fibrous tissue \& media & Haemorrhage \& overestimation
\end{tabular}}

Figure 1 Cross-sectional T2 maps of carotid arteries with atherosclerotic plaques and relative classification of main plaque components. The colour scale indicates T2 relaxation times in ms with blue corresponding to LRNC (T2<40ms), cyan to normal media or fibrous tissue (T2=40$70 \mathrm{~ms}$ ) and red to haemorrhage (long T2). Yellow represents T2 values that may be caused by incorrect overestimation or by partial volume averaging in the presence of haemorrhage. Calcification has very low proton density that produces insufficient SNR and appears black on the T2 maps. Using a semi-automated method, T2 maps were segmented into 4 tissue classes represented by the different colours at the bottom.

Table 1 T2 measurements [ms] of arterial wall and plaque tissues

\begin{tabular}{|c|c|c|c|c|c|c|c|c|}
\hline $\begin{array}{l}\text { Field } \\
\text { strength }\end{array}$ & Study & $\begin{array}{l}\text { Number of } \\
\text { TEs }\end{array}$ & $\begin{array}{l}\text { Number of } \\
\text { plaques }\end{array}$ & Location & $\begin{array}{l}\text { LRNC } \\
{[\mathrm{ms}]}\end{array}$ & $\begin{array}{l}\text { Fibrous tissue } \\
\text { [ms] }\end{array}$ & $\begin{array}{l}\text { Normal media } \\
{[\mathrm{ms}]}\end{array}$ & References \\
\hline $1.5 \mathrm{~T}$ & $\begin{array}{l}\text { ex- } \\
\text { vivo }\end{array}$ & 10 & 8 & various & $55 \pm 3$ & $79 \pm 4$ & $81 \pm 3$ & $\begin{array}{c}\text { Toussaint et al. } \\
\text { (1995) }\end{array}$ \\
\hline $4.7 \mathrm{~T}$ & & & & & $50 \pm 3$ & $63 \pm 1$ & $65 \pm 2$ & \\
\hline $9.4 \mathrm{~T}$ & & 20 & & & $20 \pm 3$ & $30 \pm 2$ & $30 \pm 3$ & \\
\hline \multirow[t]{2}{*}{$1.5 \mathrm{~T}$} & in-vivo & 2 & 7 & carotid & $28 \pm 6$ & $51 \pm 10$ & $48 \pm 7$ & $\begin{array}{c}\text { Toussaint et al. } \\
\text { (1996) }\end{array}$ \\
\hline & $\begin{array}{l}\text { ex- } \\
\text { vivo }\end{array}$ & & & & $31 \pm 5$ & $51 \pm 9$ & $52 \pm 7$ & \\
\hline $3 T$ & $\begin{array}{l}\text { ex- } \\
\text { vivo }\end{array}$ & 7 & 14 & $\begin{array}{l}\text { aorta/ } \\
\text { iliac }\end{array}$ & $54 \pm 3$ & $89 \pm 6$ & $76 \pm 9$ & $\begin{array}{c}\text { Raynaud et al. } \\
\text { (1998) }\end{array}$ \\
\hline $9.4 \mathrm{~T}$ & $\begin{array}{c}\text { ex- } \\
\text { vivo }\end{array}$ & 7 & 3 & carotid & $35-49$ & $48-60$ & $72-76$ & $\begin{array}{c}\text { Morrisett et al. } \\
\text { (2003) }\end{array}$ \\
\hline $4.7 \mathrm{~T}$ & $\begin{array}{l}\text { ex- } \\
\text { vivo }\end{array}$ & 4 & 7 & coronary & $31 \pm 7$ & $55 \pm 11$ & $50 \pm 10$ & Sun et al. (2008) \\
\hline $3 T$ & $\begin{array}{l}\text { in- } \\
\text { vivo }\end{array}$ & 7 & 23 & carotid & $36 \pm 5$ & & & this study \\
\hline
\end{tabular}

Toussaint et al. (1995). T2-weighted contrast for NMR characterization of human atherosclerosis. Arteriosclerosis Thrombosis and Vascular Biology, 15(10)15331542. Toussaint et al. (1996). Magnetic Resonance Images Lipid, Fibrous, Calcified, Hemorrhagic, and Thrombotic Components of Human Atherosclerosis In Vivo. Circulation, 94(5)932-938. Raynaud et al. (1998). Characterization of atherosclerotic plaque components by high resolution quantitative MR and US imaging. Journal of Magnetic Resonance Imaging, 8(3)622-629. Morrisett et al. (2003). Discrimination of components in atherosclerotic plaques from human carotid endarterectomy specimens by magnetic resonance imaging ex vivo. Magnetic Resonance Imaging, 21(5)465-474. Sun et al. (2008). Automatic plaque characterization employing quantitative and multicontrast MRI. Magnetic Resonance in Medicine, 59(1)174-180. 
doi:10.1186/1532-429X-14-S1-P134

Cite this article as: Biasiolli et al:: In-vivo T2 mapping of atherosclerotic plaques in carotid arteries. Journal of Cardiovascular Magnetic Resonance 2012 14(Suppl 1):P134.

Submit your next manuscript to BioMed Central and take full advantage of:

- Convenient online submission

- Thorough peer review

- No space constraints or color figure charges

- Immediate publication on acceptance

- Inclusion in PubMed, CAS, Scopus and Google Scholar

- Research which is freely available for redistribution

Submit your manuscript at www.biomedcentral.com/submit 